\title{
Coupled response of rainfall and denitrification to solar forcing during the Holocene in Alfonso Basin
}

\section{Respuesta acoplada de la lluvia y la desnitrificación al forzamiento solar durante el Holoceno en la cuenca Alfonso}

\author{
Constanza Ricaurte-Villota ${ }^{1,2}$, Oscar González-Yajimovich ${ }^{1 *}$, Alberto Sanchez $^{3}$ \\ ${ }^{1}$ Facultad de Ciencias Marinas, Universidad Autónoma de Baja California, Km 103 carretera Tijuana-Ensenada, \\ Ensenada, Baja California, México. \\ ${ }^{2}$ Instituto de Investigaciones Marinas y Costeras “José Benito Vives De Andréis” (INVEMAR), Santa Marta, \\ Colombia. \\ ${ }^{3}$ Centro Interdisciplinario de Ciencias Marinas del Instituto Politécnico Nacional (CICIMAR-IPN), Apartado \\ postal 592, La Paz, Baja California Sur, México.
}

* Corresponding author. E-mail: yajimo@uabc.edu.mx

\begin{abstract}
The bulk sedimentary $\delta^{15} \mathrm{~N}$ record of Alfonso Basin displayed changes both from a regional source possibly associated with changes in the isotopic signal of $\mathrm{NO}_{3}{ }^{-}$dissolved in Subsurface Subtropical Water and from a climate source governed by solar forcing (total solar irradiance) over the strength of the North American monsoon (i.e., rainfall), causing intermediate water suboxia and promoting denitrification in the basin. High values of bulk sedimentary $\delta^{15} \mathrm{~N}$ (maximum of $14.5 \%$ ) agree with increases in land-derived organic matter (from $-14.8 \%$ to $49.2 \%$ ) and with a decrease in terrigenous percentage (from $84.8 \%$ to $61.6 \%$ ) during the Middle and Late Holocene, suggesting that increased rainfall and freshwater input promotes increased stratification of the water column, which inhibits vertical mixing and produces a reduction in oxygen content in an already oxygen-poor zone.
\end{abstract}

Key words: Gulf of California, North American monsoon, laminated sediment record, nitrogen isotopes, Intertropical Convergence Zone.

RESUMEN. El registro de $\delta^{15} \mathrm{~N}$ sedimentario de cuenca Alfonso mostró cambios tanto de origen regional, posiblemente asociados con cambios en la señal isotópica del $\mathrm{NO}_{3}{ }^{-}$en el Agua Subsuperficial Subtropical, como de origen climático, regidos por el forzamiento solar (irradiancia solar total) sobre la intensidad del monzón de Norteamérica (i.e., precipitación pluvial), lo cual provoca suboxia de aguas intermedias y promueve la desnitrificación en la cuenca. Valores altos de $\delta^{15} \mathrm{~N}$ sedimentario (máximo de $14.5 \%$ ) coinciden con incrementos de la materia orgánica de origen terrestre (de - $14.8 \%$ a $49.2 \%$ ) y con una disminución del porcentaje de terrígenos (de $84.8 \%$ a $61.6 \%$ ) durante el Holoceno medio y tardío, sugiriendo que un aumento en la precipitación y aporte de agua dulce ocasiona un aumento de estratificación de la columna de agua, lo cual inhibe la mezcla vertical y ocasiona la reducción en el contenido de oxígeno en la columna de agua, en una zona ya pobre en oxígeno.

Palabras clave: golfo de California, monzón de Norteamérica, registro de sedimentos laminados, isótopos de nitrógeno, Zona de Convergencia Intertropical.

\section{INTRODUCTION}

Sediments can be faithful records of the isotopic composition of oceanic nitrate when nitrate capture by primary producers in the euphotic zone is complete and there is no diagenetic alteration of the isotopic signal when the particulate nitrogen drops and is buried in the sediments (Kienast et al. 2002). Bulk sedimentary nitrogen isotope ratio $\left(\delta^{15} \mathrm{~N}\right)$ can be interpreted in various ways (Hebbeln et al. 2000): (1) as the contribution of organic nitrogen of terrestrial origin (Peters et al. 1978, Sweeney et al. 1978, Owens and Law 1989), which can alter the signal towards lower values (Peters et al. 1978, Calvert et al. 2001); (2) as an indicator of nutrient conditions during the formation of marine organic matter (Francois et al. 1992, Altabet and Francois 1994,

\section{INTRODUCCIÓN}

Los sedimentos pueden ser registros fieles de la composición isotópica del nitrato oceánico cuando la captura de nitratos por productores primarios en la zona eufótica se ha completado y no hay alteración diagenética de la señal isotópica cuando el nitrógeno particulado cae y es enterrado en los sedimentos (Kienast et al. 2002). La composición isotópica del nitrógeno $\left(\delta^{15} \mathrm{~N}\right)$ sedimentario puede ser interpretada de varias maneras (Hebbeln et al. 2000): (1) como aporte de nitrógeno orgánico de origen terrestre (Peters et al. 1978, Sweeney et al. 1978, Owens y Law 1989), que puede alterar la señal hacia valores menores (Peters et al. 1978, Calvert et al. 2001); (2) como un indicador de las condiciones de nutrientes durante la formación de materia 
Holmes et al. 1996); and (3) as an indicator of denitrification intensity in the water column (Altabet et al. 1995, Ganeshram et al. 1995). Additionally, $\delta^{15} \mathrm{~N}$ may also be potentially affected by horizontal advection of nitrate with a preformed isotopic signal (Kienast et al. 2002).

Water-column denitrification occurs only in low-oxygen environments (Sigman 2001), and imparts a characteristic isotopic signature of the dissolved $\mathrm{NO}_{3}{ }^{-}$available in the ocean (Cline and Kaplan 1975, Liu and Kaplan 1989). Oceanographic and climate variations induce changes in oxygen content in the water column, which can be reconstructed using the signal of sedimentary $\delta^{15} \mathrm{~N}$. Climate-change sensitive, low levels of oxygen may result from poor ventilation of subsurface waters, a high degree of stratification (preventing vertical mixing), and organic-matter flux associated mainly with upwelling, which produces the temporal variability of denitrification in the water column (Kienast et al. 2002, Altabet 2006, Meckler et al. 2007).

Research in the Gulf of California (GC) has suggested variations in sedimentary $\delta^{15} \mathrm{~N}$ associated with global climate changes at glacial-interglacial time scales (Keigwin and Jones 1990, Sancetta 1995, Pride et al. 1999). Pride et al. (1999) suggested that variations in nitrogen isotopes in the GC respond to global climate change associated with changes in the extent of suboxic subsurface waters supporting denitrification and amplified in the central gulf by changes in upwelling, vertical mixing, and/or the latitudinal position of the Intertropical Convergence Zone (ITCZ).

The eastern tropical North Pacific and GC sedimentary records suggest changes in redox conditions at glacialinterglacial scale, which have been attributed to changes in ventilation of North Pacific Intermediate Water (NPIW) (Keigwin and Jones 1990, Kennett and Ingram 1995, van Geen et al. 1996, Cannariato and Kennett 1999, Pride et al. 1999), although some authors have suggested that these changes may be related to a stronger influence of oxygendepleted Subsurface Subtropical Water (SSW) (Ganeshram et al. 1995, Hendy and Kennett 2003). Because of its shallow sill ( $\sim 320 \mathrm{~m})$ (Nava-Sánchez et al. 2001), NPIW does not enter Alfonso Basin (confirmed also by Obeso-Nieblas et al. 2007), so the variations found in the sedimentary $\delta^{15} \mathrm{~N}$ of this zone might be associated with changes in SSW and to variations induced by climate change.

Alfonso Basin $\left(24^{\circ} 40^{\prime} \mathrm{N}, 110^{\circ} 38^{\prime} \mathrm{W}\right)$ is a small basin with a maximum depth of $\sim 415 \mathrm{~m}$ and a shallow sill, and with great potential for recording climate and oceanographic variations in the GC and the larger-scale climatic circulation of the subtropical Pacific Ocean (Douglas et al. 2001, MonrealGómez et al. 2001). Subsurface water entering the basin is low in oxygen, and below $200 \mathrm{~m}$ the basin is suboxic to anoxic (Douglas et al. 2001), allowing the preservation of a good laminated sedimentary record in a high sedimentation rate area. The geographical and hydrographic conditions of Alfonso Basin provide an opportunity to study the coupling between climate and denitrification, since this basin is orgánica marina (Francois et al. 1992, Altabet y Francois 1994, Holmes et al. 1996); y (3) como un indicador de la intensidad de desnitrificación en la columna de agua (Altabet et al. 1995, Ganeshram et al. 1995). Adicionalmente, la señal de $\delta^{15} \mathrm{~N}$ también puede ser potencialmente afectada por la advección horizontal de nitrato con una señal isotópica preformada (Kienast et al. 2002).

La desnitrificación en la columna de agua sucede sólo en ambientes pobres en oxígeno (Sigman 2001), y concede una firma isotópica característica del $\mathrm{NO}_{3}{ }^{-}$disuelto disponible en el océano (Cline y Kaplan 1975, Liu y Kaplan 1989). Las variaciones oceanográficas y climáticas producen cambios en el contenido de oxígeno en la columna de agua, que pueden ser reconstruidos a partir de la señal de $\delta^{15} \mathrm{~N}$ sedimentario. Niveles bajos de oxígeno, sensibles a cambios climáticos, pueden ser resultado de una ventilación pobre de aguas subsuperficiales, un alto grado de estratificación (impidiendo la mezcla vertical) y el flujo de material orgánico relacionado principalmente con surgencias, lo cual provoca una variabilidad temporal de la desnitrificación en la columna de agua (Kienast et al. 2002, Altabet 2006, Meckler et al. 2007).

Investigaciones en el golfo de California (GC) han sugerido variaciones de $\delta^{15} \mathrm{~N}$ sedimentario asociadas con el cambio climático global a escala glacial-interglacial (Keigwin y Jones 1990, Sancetta 1995, Pride et al. 1999). Pride et al. (1999) sugirieron que las variaciones de isótopos de nitrógeno en el GC responden al cambio climático global asociado con cambios en la extensión de aguas subsuperficiales subóxicas que soportan la desnitrificación y amplificado en el golfo central por cambios en surgencias, mezcla vertical y/o la posición latitudinal de la Zona de Convergencia Intertropical (ZCIT).

Los registros sedimentarios del Pacífico nororiental tropical y GC sugieren cambios en el estado redox a escala glacial-interglacial, los cuales han sido atribuidos a cambios en la ventilación del Agua Intermedia del Pacífico Norte (AIPN) (Keigwin y Jones 1990, Kennett e Ingram 1995, van Geen et al. 1996, Cannariato y Kennett 1999, Pride et al. 1999); sin embargo, algunos autores han propuesto que estos cambios pueden estar relacionados con una mayor influencia del Agua Subsuperficial Subtropical (ASS) baja en oxígeno (Ganeshram et al. 1995, Hendy y Kennett 2003). Debido a su umbral somero ( $\sim 320 \mathrm{~m})$ (Nava-Sánchez et al. 2001), el AIPN no ingresa a la cuenca Alfonso (confirmado también por Obeso-Nieblas et al. 2007), por lo que las variaciones de $\delta^{15} \mathrm{~N}$ sedimentario en esta zona pueden estar asociadas con los cambios en ASS y con variaciones inducidas por el cambio climático.

La cuenca Alfonso $\left(24^{\circ} 40^{\prime} \mathrm{N}, 110^{\circ} 38^{\prime} \mathrm{W}\right)$ es una cuenca pequeña con una profundidad máxima de $\sim 415 \mathrm{~m}$ y un umbral somero, y con gran potencial para el registro de variaciones climáticas y oceanográficas en el GC y la circulación climática de mayor escala del océano Pacífico subtropical (Douglas et al. 2001, Monreal-Gómez et al. 2001). El agua subsuperficial que ingresa a la cuenca es baja en oxígeno y, 
located in the southern GC, on the northern edge of the Tropic of Cancer, in a transition zone sensitive to changes in weather conditions influenced by tropical as well as extratropical systems (fig. 1).

The hydrographic conditions of Alfonso Basin are influenced mainly by seasonal shifts in the winds. In the winter and spring, strong northwesterly winds dominate and tend to produce a thick mixed layer. During the hot summer, weak southerly winds prevail and evaporation-aided higher salinity water forms a surface stratification (Aguíniga et al. 2010). The circulation within the bay is still poorly documented, but cyclonic and anticyclonic gyres have been reported to affect the bay (Obeso-Nieblas 2003, Lavín et al. 2007). In the present time, these conditions influence the variability of $\delta^{15} \mathrm{~N}$, with larger values in spring and summer than in fall and winter. In addition, occasional high $\delta^{15} \mathrm{~N}$ values suggest that physical mechanisms, such as the shoaling and advection into the bay of ${ }^{15} \mathrm{~N}$-rich subsurface equatorial water, occur over short time periods, which is presumed to be related to the periodic development of a major cyclonic gyre in the southern GC (Aguíniga et al. 2010).

The North American monsoon is the main factor influencing climate variability over the region and it is caused by a dynamic interaction between mid-latitude weather systems,

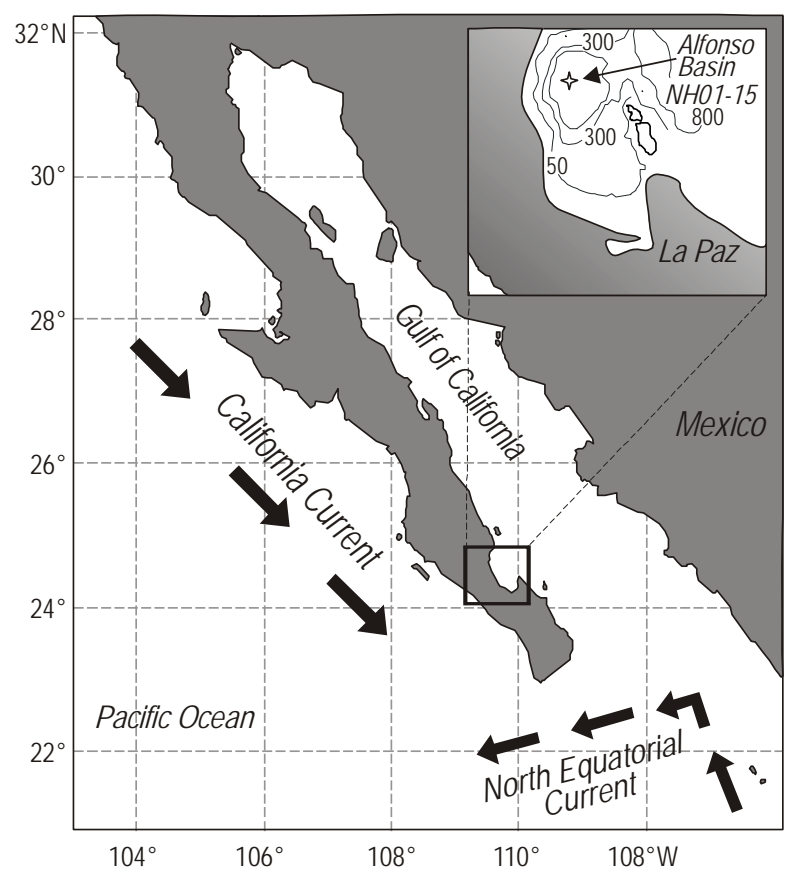

Figure 1. Map of the Gulf of California (Mexico) showing Alfonso Basin, the location of the cores (black point) used in this study, and the surface currents around the area. The inset shows the bathymetry.

Figura 1. Mapa del golfo de California (México) que muestra la cuenca Alfonso, la ubicación de los núcleos (punto negro) usados en este estudio y las corrientes superficiales en la zona. El inserto muestra la batimetría. por debajo de los $200 \mathrm{~m}$ de profundidad, la cuenca está entre subóxica y anóxica (Douglas et al. 2001), lo que permite la preservación de un buen registro de sedimentos laminados en una zona con una alta tasa de sedimentación. Las condiciones geográficas e hidrográficas de la cuenca Alfonso proveen una oportunidad para estudiar el acoplamiento entre el clima y la desnitrificación, ya que esta cuenca se localiza en la parte sur del GC, en el extremo norte del trópico de Cáncer, en una zona de transición sensible a cambios en las condiciones climáticas influenciadas por sistemas tropicales y extratropicales (fig. 1).

Las condiciones hidrográficas de la cuenca Alfonso están influenciadas principalmente por los cambios estacionales de los vientos. En el invierno y la primavera, los vientos fuertes del noroeste predominan y tienden a producir una capa de mezcla profunda. Durante el verano caluroso, predominan los vientos débiles del sur y el agua más salina, por causa de mayor evaporación, forma una estratificación superficial (Aguíñiga et al. 2010). La circulación dentro de la bahía aún no está bien documentada, pero se ha observado que ésta es afectada por giros ciclónicos y anticiclónicos (Obeso-Nieblas 2003, Lavín et al. 2007). Actualmente, estas condiciones influencian la variabilidad de $\delta^{15} \mathrm{~N}$, con valores mayores en primavera y verano que en otoño e invierno. Además, valores ocasionalmente altos de $\delta^{15} \mathrm{~N}$ sugieren que mecanismos físicos, como la advección hacia la bahía de agua ecuatorial subsuperficial rica en ${ }^{15} \mathrm{~N}$, se presentan durante periodos cortos de tiempo, lo que se cree está relacionado con el desarrollo periódico de un importante giro ciclónico en la parte sur del GC (Aguíñiga et al. 2010).

El monzón de Norteamérica es el principal factor que influye en la variabilidad climática de la región y es causado por una interacción dinámica entre los sistemas meteorológicos de latitudes medias, los procesos atmósfericos tropicales impulsados por el océano y el calentamiento diferencial entre la tierra y el océano (Douglas et al. 2007). El monzón se caracteriza por precipitación de verano, que muestra variabilidad a diferentes escalas de tiempo (Castro et al. 2000, Hu y Feng 2002, Gray et al. 2003, González-Yajimovich et al. 2004, Poore et al. 2005).

La variabilidad decadal del monzón está asociada con la Oscilación Decadal del Pacífico (ODP), un patrón de las fluctuaciones de la temperatura superficial del Pacífico Norte que cambia de fase cada 20 a 30 años (Mantua et al. 1997). La fase positiva (cálida) de la ODP se asemeja a las anomalías de precipitación pluvial y temperatura de tipo El Niño, con mayor precipitación en el invierno en la zona de estudio (Magaña 1999). La fase negativa (fría) de la ODP se asemeja a patrones climáticos de La Niña (Mantua et al. 1997). Los patrones de precipitación invernal son resultado de la intensidad y posición del centro de baja presión de las Aleutianas, que se fortalece y/o se ubica más al este durante una fase positiva y se debilita y/o se ubica más al oeste durante una fase negativa de la ODP. El centro de alta presión del Pacífico Norte se comporta de manera opuesta al del centro de baja 
tropical ocean-driven atmospheric processes, and the differential heating between land and ocean (Douglas et al. 2007). The monsoon is characterized by summer rainfall, which shows variability on different time scales (Castro et al. 2000, $\mathrm{Hu}$ and Feng 2002, Gray et al. 2003, González-Yajimovich et al. 2004, Poore et al. 2005).

The decadal timescale variability of the monsoon is associated with the Pacific Decadal Oscillation (PDO), a pattern of North Pacific sea surface temperature fluctuation that shifts its phase every 20-30 years (Mantua et al. 1997). The positive PDO (warm) phase resembles El Niño-like North American temperature and precipitation anomalies, with increased winter precipitation in the study area (Magaña 1999). The negative PDO phase (cool) resembles La Niñalike climate patterns (Mantua et al. 1997). The winter precipitation patterns result from the strength and position of the Aleutian Low, which becomes stronger and/or is located further to the east during a positive PDO phase and is weakened and/or located more to the west during a negative PDO. The North Pacific High behaves in a synchronized manner opposite to the Aleutian Low. It is weaker and more to the south in the summer during a positive PDO phase and is strengthened and more to the north during a negative PDO (Barron and Anderson 2011).

This study of mid- to late-Holocene sedimentary $\delta^{15} \mathrm{~N}$ shows dynamics at decadal time scales in the GC, caused by the influence of solar radiation on rainfall. Other records for the study region show variations at glacial-interglacial time scales (Altabet et al. 1995, Ganeshram et al. 1995), making this study the first to use such a high-resolution record in the region. The paleoproductivity and terrestrial flux reconstruction dataset considered together with the isotopic data could yield critical new insights into how the GC has evolved over the last 6000 years.

\section{MATERIALS AND METHODS}

Sediment cores from Alfonso Basin (gravity core NH01$15 \mathrm{GC} 3,308 \mathrm{~cm}$, and multicore $\mathrm{NH} 01-15 \mathrm{MC} 1,40 \mathrm{~cm}$ ), spanning $\sim 5.6$ kilo years before present (kyr BP), were recovered during the CalMex NH01 cruise in November and December 2001 on board the R/V New Horizon. Sediment cores were sampled at $1-\mathrm{cm}$ intervals, equivalent to $\sim 26.7 \mathrm{yr}$, to produce a high resolution record of bulk sedimentary $\delta^{15} \mathrm{~N}$, biogenic silica (BSi), total organic carbon (TOC), carbonates $\left(\mathrm{CaCO}_{3}\right)$, terrigenous content, relative percent of landderived organic matter (\%TOM), and molar $\mathrm{C}: \mathrm{N}$ ratio.

The bulk sedimentary nitrogen isotopes $\left(\delta^{15} \mathrm{~N}\right)$ were used to trace changes in oxic conditions due to variations in the intensity of vertical mixing during periods of higher and lower rainfall, as well as changes in the flow of organic matter to the sediments (TOC, $\mathrm{BSi}$, and $\mathrm{CaCO}_{3}$ ) and organic matter inputs of terrigenous origin. Nitrogen isotopes were obtained using a EuroVector (Euro EA 3000) elemental analyzer at the University of Southern California (USC). presión de las Aleutianas, ya que es más débil y se ubica más al sur en el verano durante una fase positiva y es más fuerte y se ubica más al norte durante una fase negativa de la ODP (Barron y Anderson 2011).

Este registro de $\delta^{15} \mathrm{~N}$ sedimentario del Holoceno medio y tardío muestra la dinámica en el GC a una escala de tiempo decadal, regida por la influencia de la radiación solar en la precipitación. Otros registros para la zona de estudio muestran variaciones a una escala de tiempo glacial-interglacial (Altabet et al. 1995, Ganeshram et al. 1995), por lo que este trabajo es el primero en presentar un registro de tan alta resolución para la región. Los datos de paleoproductividad y reconstrucción del flujo terrestre considerados con los datos isotópicos pueden proporcionar mayor conocimiento de cómo ha evolucionado el GC durante los últimos 6000 años.

\section{MATERIALES Y MÉTODOS}

Se obtuvieron núcleos de sedimentos de la cuenca Alfonso (núcleo de gravedad NH01-15GC3, $308 \mathrm{~cm}$, y multinúcleo NH01-15MC1, $40 \mathrm{~cm}$ ), abarcando $\sim 5.6$ miles de años antes del presente (ka AP), durante el crucero CalMex NH01 realizado a bordo del B/I New Horizon en noviembre y diciembre de 2001. Los núcleos se muestrearon a intervalos de $1 \mathrm{~cm}$, equivalente a $\sim 26.7$ años, para producir un registro de alta resolución de $\delta^{15} \mathrm{~N}$ sedimentario, sílice biogénico (BSi), carbono orgánico total (COT), carbonatos $\left(\mathrm{CaCO}_{3}\right)$, contenido terrígeno, porcentaje relativo de materia orgánica de origen terrestre (\%MOT) y razón molar $\mathrm{C}: \mathrm{N}$.

Los isótopos de nitrógeno $\left(\delta^{15} \mathrm{~N}\right)$ sedimentario fueron usados para trazar cambios en las condiciones óxicas debido a variaciones en la intensidad de mezcla vertical durante periodos de mayor y menor precipitación pluvial, así como cambios en el flujo de materia orgánica hacia los sedimentos $\left(\mathrm{COT}, \mathrm{BSi}\right.$ y $\mathrm{CaCO}_{3}$ ) y aportes de materia orgánica terrestre. Los isótopos se obtuvieron con un analizador elemental EuroVector (Euro EA 3000) en la Universidad del Sur de California (USC).

Puesto que la desnitrificación en la columna de agua puede ser potencialmente afectada por la variación en la entrada de materia orgánica degradable a los sedimentos (Kienast et al. 2002, Altabet 2006, Meckler et al. 2007), la determinación de estos flujos es esencial para entender los cambios en la desnitrificación. En este estudio se usaron varios biomarcadores (e.g., $\mathrm{COT}, \mathrm{BSi}, \mathrm{CaCO}_{3}$ ) para conocer el flujo de materia orgánica en la cuenca Alfonso, ya que esto permite excluir los efectos de degradación en los diferentes trazadores de productividad (Versteegh y Zonneveld 2002). Se obtuvieron el carbono total con un analizador elemental EuroVector (Euro EA 3000), el carbono inorgánico (para los carbonatos) con un coulómetro de dióxido de carbono (UIC Inc., modelo CM5014) y el carbono orgánico mediante una simple resta.

El BSi se usó como un trazador de la productividad, relacionada con surgencias y diatomeas, y para confirmar las 
As denitrification in the water column can potentially be affected by the variation in the input of degradable organic matter to the sediments (Kienast et al. 2002, Altabet 2006, Meckler et al. 2007), the determination of these flows is critical to understanding the changes in denitrification. This study used several biomarkers (e.g., TOC, $\mathrm{BSi}, \mathrm{CaCO}_{3}$ ) to understand the flow of organic matter in Alfonso Basin, as this allows us to exclude the effects of degradation on the different tracers of productivity (Versteegh and Zonneveld 2002). Total carbon was obtained using a EuroVector (Euro EA 3000) elemental analyzer, inorganic carbon (for $\mathrm{CaCO}_{3}$ ) was obtained using a carbon dioxide coulometer (UIC Inc., model CM5014), and organic carbon was obtained by a simple subtraction.

Biogenic silica was used as a tracer for productivity, related to upwelling and diatoms, and to confirm the observations made on variations of the percent of TOC, as this tracer is less sensitive to the redox conditions of the sediment. It was obtained by the spectrophotometric method (Mortlock and Froelich 1989). The BSi digestion was continuous over time, and the extractions were performed in 5-h time series; after this time it was considered that the extraction of the BSi content in the sample would not change with increased extraction time.

The terrigenous fraction of marine sedimentary records reflects the input of material produced and discharged from the continents, which is directly related to the climatic conditions within them (Holz et al. 2007). Terrigenous mass accumulation rates were obtained by González-Yajimovich (2004), by subtracting the biogenic components from the total mass accumulation rates.

The \%TOM and molar C:N ratio were used together to confirm changes in rainfall. The \%TOM was calculated from the isotopic carbon composition $\left(\delta^{13} \mathrm{C}\right)$ of sedimentary organic matter. Carbon isotopes were obtained using a Thermo Scientific Delta V Plus isotope-ratio mass spectrometer coupled to a Costech 4010 elemental analyzer at the Mass Spectrometry Laboratory of CICIMAR-IPN. The approach is based on the mixing model proposed by Schultz and Calder (1976), which assumes $\delta^{13} \mathrm{C}$ values of several terrestrial and marine end-members. For this study we used the end-member values of Aguíniga et al. (2010). We assumed a $\delta^{13} \mathrm{C}$ value of $-28 \%$ for the terrestrial end-member and of $-20.5 \%$ or the marine end-member. We believe that these end-members are the real values for the study area and the contributions of land-derived organic matter defined by the $\delta^{13} \mathrm{C}$ are robust. Adopting the above end-member values, $\% \mathrm{TOM}$ was estimated based on the following equation (Schultz and Calder 1976):

$$
\% \mathrm{TOM}=\frac{\delta^{13} \mathrm{C}_{\text {marine }}-\delta^{13} \mathrm{C}_{\mathrm{TOC}}}{\delta^{13} \mathrm{C}_{\text {marine }}-\delta^{13} \mathrm{C}_{\text {terrestrial }}} \times 100
$$

observaciones realizadas de las variaciones del porcentaje de COT, ya que este trazador es menos sensible a las condiciones redox del sedimento. Se obtuvo mediante el método espectrofotométrico (Mortlock y Froelich 1989). La digestión del BSi fue continua en el tiempo, y las extracciones se realizaron en series de tiempo de $5 \mathrm{~h}$; después de este tiempo se consideró que la extracción del contenido de BSi en la muestra no cambiaría con un mayor tiempo de extracción.

La fracción terrígena de los registros de sedimentos marinos refleja el aporte del material producido y aportado de los continentes, el cual está directamente relacionado con las condiciones climáticas (Holz et al. 2007). GonzálezYajimovich (2004) obtuvo las tasas de acumulación de masa terrígena al restar los componentes biogénicos de las tasas de acumulación de masa total.

El \%MOT y la razón molar C:N se usaron en conjunto para confirmar los cambios de la precipitación pluvial. El \%MOT fue calculado a partir de la composición isotópica de carbono $\left({ }^{13} \mathrm{C}\right)$ de la materia orgánica sedimentaria. Los isótopos del carbono fueron obtenidos con un espectrómetro de masas de relación isotópica (Thermo Scientific Delta V Plus) acoplado a un analizador elemental (Costech 4010) en el Laboratorio de Espectrometría de Masas del CICIMARIPN. El enfoque se basa en el modelo de mezcla propuesto por Schultz y Calder (1976), el cual supone valores de $\delta^{13} \mathrm{C}$ de varios miembros terminales terrestres y marinos. Para este estudio se usaron los valores de miembros terminales de Aguíniga et al. (2010). Se supuso un valor de $\delta^{13} \mathrm{C}$ de $-28 \%$ o para el miembro terminal terrestre y de $-20.5 \%$ para el miembro terminal marino. Pensamos que estos miembros terminales son los valores reales para la zona de estudio y que las contribuciones de la materia orgánica de origen terrestre definidas por $\delta^{13} \mathrm{C}$ son robustas. Adoptando tales valores, se estimó el \%MOT con base en la siguiente ecuación (Schultz y Calder 1976):

$$
\% \text { MOT }=\frac{\delta^{13} \mathrm{C}_{\text {marino }}-\delta^{13} \mathrm{C}_{\mathrm{COT}}}{\delta^{13} \mathrm{C}_{\text {marino }}-\delta^{13} \mathrm{C}_{\text {terrestre }}} \times 100
$$

Los miembros terminales son promedios grandes de materia terrestre y marina que llega al océano; por lo tanto, debido a la gran diversidad de fuentes de materia orgánica (fitoplancton, zooplancton, macroalgas, etc.), el asumir un solo valor tiene sus limitaciones, aunque se considera que el fitoplancton es el principal contribuyente a la materia orgánica. Otra limitación se presenta al suponer que la materia orgánica proveniente de cada fuente tiene el mismo proceso de degradación y las mismas proporciones de los componentes. Ni C ni $\mathrm{N}$ tienen el mismo proceso de diagénesis; sin embargo, la materia orgánica terrestre (más refractaria) es relativamente más fuerte que la materia orgánica marina (más lábil). A pesar de esto, los miembros terminales dan una buena idea de las fuentas principales y dominantes en la región (Aguíniga et al. 2010, Sánchez et al. 2013). 
End-members are large averages of land and marine matter reaching the ocean; therefore, because of the great diversity of organic matter sources (phytoplankton, zooplankton, macroalgae, etc.), assuming a single value has its limitations, though it is considered that phytoplankton is the main contributor to organic matter. Another limitation comes from assuming that the organic matter originating from each source has the same degradation process and proportions of the components. Neither $\mathrm{C}$ nor $\mathrm{N}$ have the same process of diagenesis; however, the terrestrial organic matter (more refractory) is relatively stronger than the marine organic matter (more labile). Despite this the end-members give a good idea of the primary and dominant sources in the region (Aguíniga et al. 2010, Sánchez et al. 2013).

The C:N ratio of the organic matter was used to confirm its true source. Marine organic matter typically is in the range of 4 to 10 (Meyers 1994) and terrestrial organic matter is characterized by a C:N > 12 (Hedges et al. 1986).

The age-depth model for cores NH01-15GC3 and NH01$15 \mathrm{MC} 1$ (fig. 2) is discussed in detail in González-Yajimovich (2004) and González-Yajimovich et al. (2007). It was constructed using a combination of excess ${ }^{210} \mathrm{~Pb}$ profiles, six accelerator mass spectrometry (AMS) radiocarbon dates performed to samples of benthic and planktonic foraminifera, and varve counts on gray-scale digital transformations from X-ray positives. The ${ }^{14} \mathrm{C}$ dates were converted to calendar years using the CALIB 4.4.1 software (Stuiver and Reimer 1993).

The influence of solar forcing was traced using the difference of total solar irradiance (dTSI), corresponding to the TSI reconstruction of Steinhilber et al. (2009) using cosmogenic radionuclides; dTSI is the difference between the values of TSI reconstructed and the minimum TSI of 1986 AD (1365.57 $\mathrm{W} \mathrm{m}^{-2}$ ) of Frohlich (2009).

Factor analysis was performed to compare the interrelationship between the different proxies, using the Minitab 15 program. The angle between vectors measures the relationship between proxies. Stronger relationships have closer angles (near zero). An angle of $180^{\circ}$ means that the proxies are inversely related and if the vectors are at right angles, then the proxies are uncorrelated.

Significant frequencies and dominant modes of climate variability were calculated by the multi-taper spectral analysis (MTM, Mann and Lees 1996) of $\delta^{15} \mathrm{~N}, \% \mathrm{TOM}$, and dTSI anomalies.

\section{RESULTS AND DISCUSSION}

The Alfonso Basin record shows a coupled response of rainfall and denitrification to dTSI. High values of dTSI correlated with high $\delta^{15} \mathrm{~N}$ values (4.4-2.4 kyr BP) and high rainfall (increase in \%TOM and C:N ratio) (fig. 3), and were confirmed by the factor analysis (fig. 4). In this period the magnitude of change increases, suggesting system instability.
Se usó la razón C:N de la materia orgánica para confirmar su fuente verdadera. La materia orgánica marina típicamente presenta un intervalo de 4 a 10 (Meyers 1994) y la terrestre se caracteriza por una C:N > 12 (Hedges et al. 1986).

El modelo de edad-profundidad para los núcleos NH0115GC3 y NH01-15MC1 (fig. 2) se discute en detalle en González-Yajimovich (2004) y González-Yajimovich et al. (2007). Se construyó usando una combinación de perfiles del exceso de ${ }^{210} \mathrm{~Pb}$, seis fechas de radiocarbono de la espectrometría de masas con aceleradores aplicada a muestras de foraminíferos bentónicos y planctónicos, y conteos de varves en transformaciones digitales en escala de grises de positivos de rayos $\mathrm{X}$. Las fechas de ${ }^{14} \mathrm{C}$ fueron convertidas en años de calendario con el programa CALIB 4.4.1 (Stuiver y Reimer 1993).

La influencia del forzamiento solar se determinó mediante la diferencia de la irradiación solar total (dIST), que corresponde a la reconstrucción de la IST de Steinhilber et al. (2009) con radionucleidos cosmogénicos. La dIST es la diferencia entre los valores de la IST reconstruida y la IST mínima de 1986 AD (1365.57 $\mathrm{W} \mathrm{m}^{-2}$ ) de Frohlich (2009).

Se realizó un análisis factorial para comparar la interrelación entre los diferentes trazadores con el programa Minitab 15. Los ángulos entre los vectores muestran la relación entre los trazadores. Las relaciones más fuertes tienen ángulos más pequeños (cerca de cero). Un ángulo de $180^{\circ}$ indica que los trazadores están inversamente relacionados y si los vectores forman ángulos rectos, los trazadores no están correlacionados.

Se calcularon frecuencias significativas y modos dominantes de la variación climática mediante el análisis espectral multitaper (MTM, Mann y Lees 1996) de $\delta^{15} \mathrm{~N}$, \%MOT y anomalías de dIST.

\section{RESULTADOS Y DISCUSIÓN}

El registro de la cuenca Alfonso muestra una respuesta acoplada de la precipitación pluvial y la desnitrificación a la dIST. Valores altos de dIST se correlacionaron con valores altos de $\delta^{15} \mathrm{~N}(4.4-2.4 \mathrm{ka} \mathrm{AP})$ y con una precipitación alta (aumento del \%MOT y la razón C:N) (fig. 3), y fueron confirmados por el análisis factorial (fig. 4). Durante este periodo incrementa la magnitud del cambio, lo que sugiere inestabilidad del sistema. La materia orgánica de origen terrestre generalmente tiene un valor bajo de $\delta^{15} \mathrm{~N}$, por lo que los valores altos de $\delta^{15} \mathrm{~N}$ de la cuenca Alfonso no reflejan la contribución de la señal del material terrestre sino más bien la presencia de desnitrificación en la cuenca, acoplada con la señal de la ASS (con valores altos de $\delta^{15} \mathrm{~N}$ ) que llega a la cuenca. Una gráfica cruzada del \%MOT y $\delta^{15} \mathrm{~N}$ de la materia orgánica que se hunde, recolectada por una trampa de sedimento (Aguíniga et al. 2010), muestra que la composición isotópica del $\mathrm{N}$ particulado es menor cuando la contribución terrestre aumenta; sin embargo, la correlación es baja, lo que confirma una baja contribución de la señal de la materia 


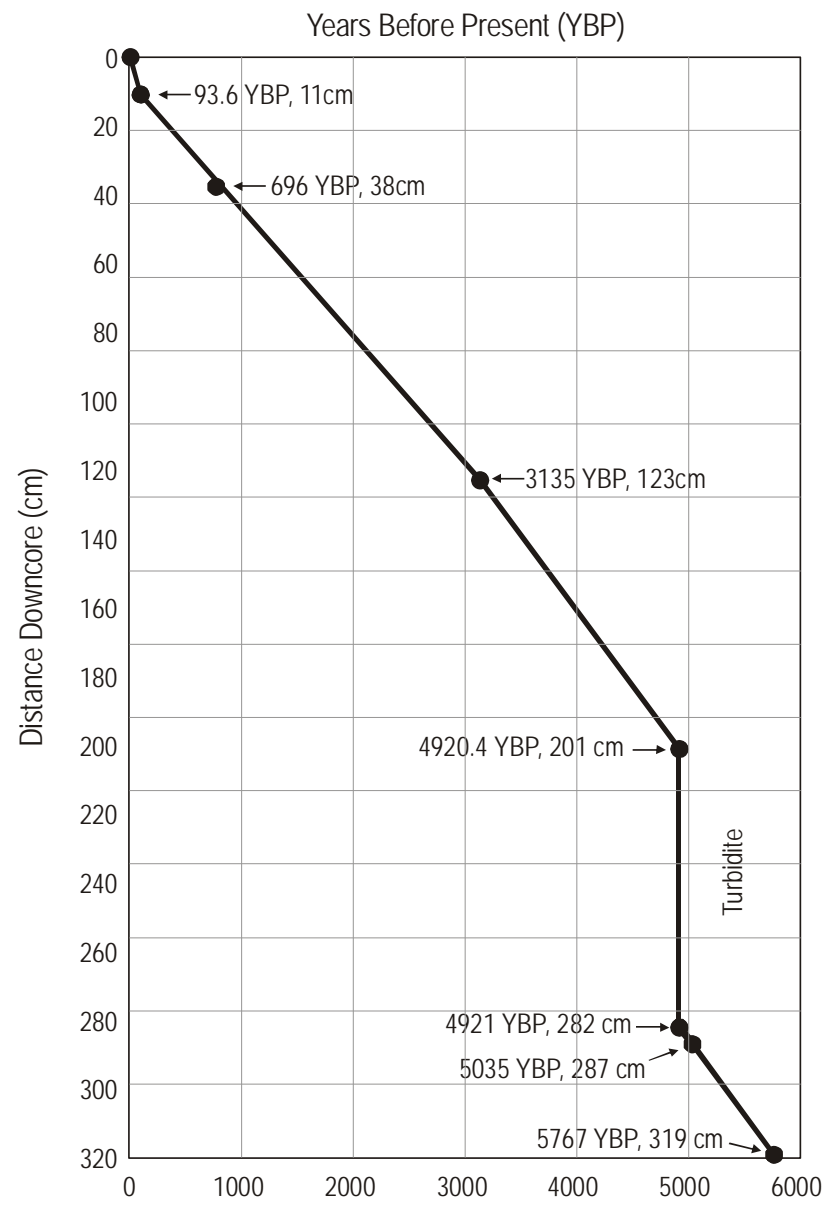

Figure 2. Age model for Alfonso Basin sediment cores NH01$15 \mathrm{GC} 3$ and $\mathrm{NH} 01-15 \mathrm{MC} 1$ based on ${ }^{14} \mathrm{C}$ and ${ }^{210} \mathrm{~Pb}$ data (from González-Yajimovich 2004, González-Yajimovich et al. 2007).

Figura 2. Modelo de edad para los núcleos NH01-15GC3 y NH01-15MC1 de la cuenca Alfonso con base en datos de ${ }^{14} \mathrm{C}$ y ${ }^{210} \mathrm{~Pb}$ (de González-Yajimovich 2004, González-Yajimovich et al. 2007).

Land-derived organic matter usually has a low $\delta^{15} \mathrm{~N}$ value, so the high $\delta^{15} \mathrm{~N}$ values from Alfonso Basin do not reflect the contribution of the isotopic signal of terrestrial material but rather that denitrification is occurring in the basin, coupled with the signal of SSW (with high values of $\delta^{15} \mathrm{~N}$ ) arriving at the basin. A \%TOM and $\delta^{15} \mathrm{~N}$ cross-plot of sinking sedimenttrap organic matter (Aguíniga et al. 2010) shows a trend in which the isotopic composition of particulate $\mathrm{N}$ is lower when the terrestrial contribution increases; however, the correlation is low, which confirms a low contribution of the land-derived organic matter signal to the $\delta^{15} \mathrm{~N}$ isotopic values in the sediments of Alfonso Basin.

The decrease in percent terrigenous content (fig. 3) in the period of high values of $\delta^{15} \mathrm{~N}$ and rainfall proxies $(\% \mathrm{TOM}$ and $\mathrm{C}: \mathrm{N}$ ratio) is probably associated with a decrease in the winds, common in the study area during the rainy season, and also with greater vegetation cover that catches the sediments. orgánica terrestre a los valores de $\delta^{15} \mathrm{~N}$ en los sedimentos de la cuenca Alfonso.

La disminución del porcentaje de contenido terrígeno (fig. 3) durante el periodo de los valores altos de $\delta^{15} \mathrm{~N}$ y los trazadores de la precipitación pluvial (\%MOT y razón $\mathrm{C}: \mathrm{N})$ probablemente está relacionada con una disminución de los vientos, lo cual es común en la zona de estudio durante la época de lluvias, así como con una mayor cobertura de vegetación que atrapa los sedimentos. Una disminución del componente litogénico durante eventos de El Niño fue observado en el GC por Thunell (1998) y en la cuenca de San Lázaro por Silverberg et al. (2004), y se atribuyó a vientos más calmados desde el continente y a la reducción del transporte eólico de partículas. Las condiciones climáticas de estas zonas son similares a las de la cuenca Alfonso. El Niño produce condiciones de verano (i.e., condiciones más húmedas y cálidas), permitiendo una mayor influencia tropical. La relación no es completamente inversa ya que la contribución de material terrígeno a los sedimentos marinos tiene dos rutas, eólica y fluvial (Zhao et al. 2006), ambas afectadas de manera diferente durante periodos de lluvias.

Nuestros resultados también concuerdan con los de Pérez-Cruz (2013), quien documentó un aumento de la escorrentía y la bioproductividad para el Holoceno medio (ca. 6.2 a 2.4 ka AP), asociado con una intensificación de las lluvias monzonales desencadenadas por un cambio hacia el norte de la posición media de la ZCIT en el Pacífico oriental tropical. En nuestro registro el periodo va de ca. 4.4 a $2.4 \mathrm{ka} \mathrm{AP,} \mathrm{por} \mathrm{lo}$ que la concordancia no es totalmente sincrónica. Además, nuestro registro coincide con el periodo de sequía documentado de 2.4 a $1.9 \mathrm{ka}$ AP.

Las variaciones de $\delta^{15} \mathrm{~N}$ en sedimentos de la cuenca Alfonso corresponden a la señal isotópica regional del Pacífico nororiental tropical, pero los valores de $\delta^{15} \mathrm{~N}$ son mucho más altos que los observados en los registros de las zonas más al norte. Los cambios en $\delta^{15} \mathrm{~N}$ observados en el presente estudio y en la cuenca de Guaymas (Pride et al. 1999), pero no en otros sitios, son una indicación de efectos regionales y evidencia de activa desnitrificación en estas cuencas en el pasado.

Se han atribuido cambios de $\delta^{15} \mathrm{~N}$ en la región del Pacífico nororiental a cambios de desnitrificación en el ASS pero a escala glacial-interglacial (Ganeshram et al. 1995). Los registros para el Holoceno del golfo de Tehuantepec (Hendy y Pedersen 2006), el margen de Mazatlán (Ganeshram et al. 2000), y los márgenes de California y Oregon (Kienast et al. 2002) (fig. 5) mostraron cambios de pequeña amplitud en la señal de $\delta^{15} \mathrm{~N}$, posiblemente asociados con la señal del ASS.

El aumento de la productividad marina en zonas con bajo contenido de oxígeno es considerado un mecanismo que promueve la desnitrificación (Devol 1978, Codispoti y Christensen 1985) al consumirse el oxígeno en la columna de agua por el hundimiento y la oxidación de materia orgánica (van Geen et al. 2003); además, las bacterias desnitrificadoras usan nitratos como aceptores de electrones y estimulan el 


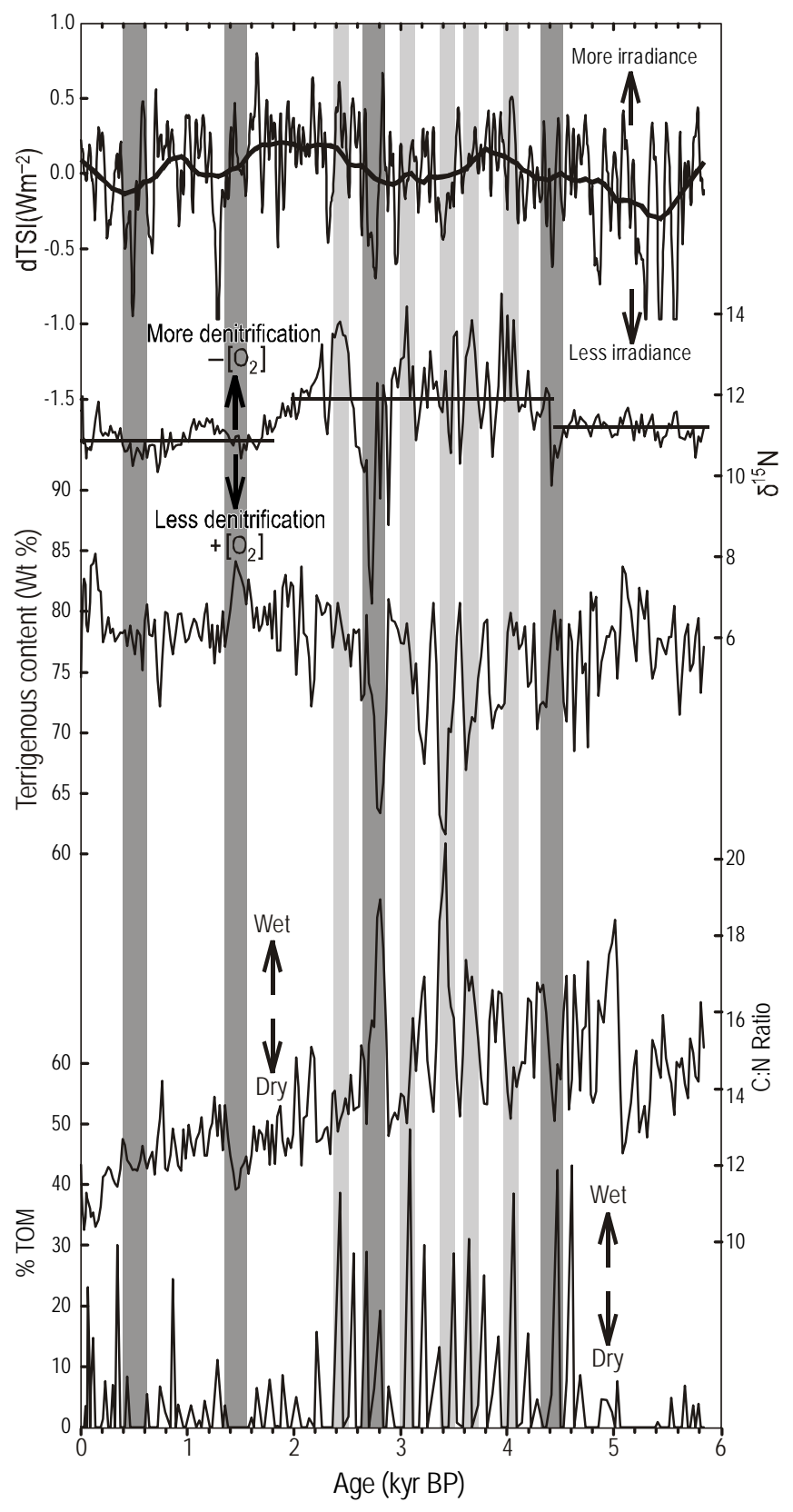

Figure 3. Comparison of global irradiation to sedimentary records from Alfonso Basin: difference of total solar irradiance record (dTSI) (Steinhilber et al. 2009), running average of 50 years (heavy line); bulk sedimentary $\delta^{15} \mathrm{~N}$ (denitrification indicator); terrigenous content ( $\mathrm{Wt} \%$ ); organic matter $\mathrm{C}: \mathrm{N}$ ratio; and percent of land-derived organic matter (\%TOM) (the latter two used as indicators of rainfall in Alfonso Basin).

Figura 3. Comparación de la irradiación global con los registros sedimentarios de la cuenca Alfonso: diferencia del registro de la irradiación solar total (dTSI) (Steinhilber et al. 2009), promedio de 50 años (línea gruesa); $\delta^{15} \mathrm{~N}$ sedimentario (indicador de la desnitrificación); contenido terrígeno (Wt \%); razón C:N de la materia orgánica; y porcentaje de materia orgánica de origen terrestre (\%TOM) (los últimos dos se usaron como indicadores de la precipitación pluvial en la cuenca Alfonso).

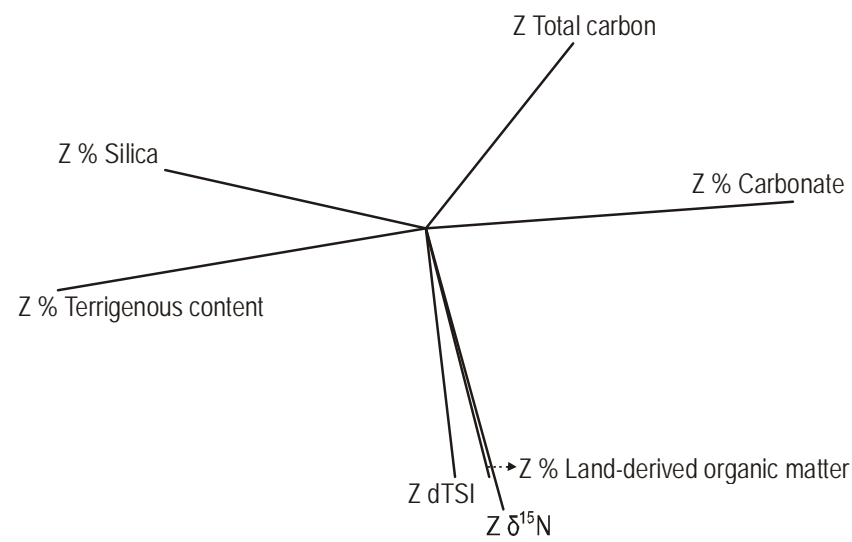

Figure 4. Factor analysis applied to standardized anomalies of the different proxies of productivity, rainfall, and denitrification in Alfonso Basin, and standardized anomalies of the difference of total solar irradiance for the Holocene (dTSI) of Steinhilber et al. (2009).

Figura 4. Análisis factorial aplicado a las anomalías estandarizadas de los diferentes trazadores de la productividad, precipitación pluvial y desnitrificación, y las anomalías estandarizadas de la diferencia de la irradiación solar total para el Holoceno (dTSI) de Steinhilber et al. (2009).

proceso respiratorio de la desnitrificación (Altabet et al. 1999). En la cuenca Alfonso, la relación entre la desnitrificación y la productividad marina no es clara (fig. 6) y se observan dos modos de respuesta: (1) el modo de alta precipitación pluvial en la parte media del registro (4.4-2.4 ka AP), con la desnitrificación dominada por los cambios en la estratificación de la columna de agua inferida por valores altos de $\delta^{15} \mathrm{~N}$ y precipitación, y valores bajos de productividad; y (2) el modo de baja precipitación pluvial (5.8-4.4 ka AP y 2.4 ka AP-presente), con la desnitrificación dominada por los cambios en la productividad, siendo sincrónicos los cambios en ambos trazadores. Asimismo, durante el periodo de alta precipitación pluvial, la señal de $\delta^{15} \mathrm{~N}$ se encuentra desacoplada de la sedimentación (respondiendo a mecanismos físicos, fuerte estratificación de la columna de agua debido a las lluvias, generando anoxia). Durante el periodo cuando la productividad se encuentra acoplada a la desnitrificación (modo de baja precipitación), la sedimentación y preservación local de $\mathrm{BSi}$ y $\mathrm{CaCO}_{3}$ no están bien acopladas al carbono orgánico, probablemente porque $\mathrm{BSi}$ y $\mathrm{CaCO}_{3}$ se originan de diferentes grupos de productores que responden a diferentes condiciones climáticas del océano y porque diversos procesos afectan estos trazadores durante su transporte y acumulación. Además, el COT presenta limitaciones como trazador ya que la fracción de carbono orgánico exportada y preservada en los sedimentos no es constante a través del tiempo y espacio, y depende de múltiples factores como la productividad superficial, la estacionalidad (Berger et al. 1989), la tasa de sedimentación (Müller y Suess 1979), el tamaño de grano del sedimento y área superficial (Hedges y 
A decrease in the lithogenic component during El Niño events was observed in the GC by Thunell (1998) and in San Lázaro Basin by Silverberg et al. (2004), and was attributed to calmer winds from the continent and reduced eolian dust transport. These are areas with similar climatic conditions as Alfonso Basin. El Niño produces summer-like conditions (i.e., wetter and warmer conditions) allowing for greater tropical influence. The relationship is not completely inverse (fig. 4) since the contribution of terrigenous material to the marine sediments has two routes, eolic and fluvial (Zhao et al. 2006), both affected in a different way during periods of rainfall.

Our results also agree with the findings of PérezCruz (2013), who reported an increase in runoff and bioproductivity for the Middle Holocene (ca. 6.2 to 2.4 kyr BP), associated with a strengthening of the monsoonal precipitation triggered by a northward shift of the ITCZ mean position in the eastern tropical Pacific. The agreement is not completely synchronic since in our record this period goes from ca. 4.4 to $2.4 \mathrm{kyr}$ BP. Likewise, our record coincides with the drought period reported from 2.4 to $1.9 \mathrm{kyr}$ BP.

Variations in the sedimentary $\delta^{15} \mathrm{~N}$ of Alfonso Basin correspond to the base regional isotopic signal of the eastern tropical North Pacific, but $\delta^{15} \mathrm{~N}$ values are much higher than those observed in the northernmost records. The occurrence of changes in $\delta^{15} \mathrm{~N}$ observed in this study and in Guaymas Basin (Pride et al. 1999), but not at other locations, is an indication of regional effects and evidence of active denitrification within these basins in the past.

Changes in $\delta^{15} \mathrm{~N}$ in the eastern North Pacific region have been attributed to changes in denitrification in SSW but at glacial-interglacial time scales (Ganeshram et al. 1995). Likewise, records for the Holocene from the Gulf of Tehuantepec (Hendy and Pedersen 2006), Mazatlán margin (Ganeshram et al. 2000), and the California and Oregon margins (Kienast et al. 2002) (fig. 5) showed small-amplitude changes in the $\delta^{15} \mathrm{~N}$ signal, possibly also associated with the SSW signal.

The increase in marine productivity in zones with low oxygen content is considered a mechanism that promotes denitrification (Devol 1978, Codispoti and Christensen 1985) because the sinking and oxidation of organic matter consumes the oxygen in the water column (van Geen et al. 2003) and denitrifying bacteria use nitrate as an electron acceptor, stimulating the respiratory reductive process of denitrification (Altabet et al. 1999). In Alfonso Basin the relationship between denitrification and marine productivity is not clear (fig. 6) and two modes of basin response are observed: (1) high rainfall mode through the middle of the record (4.4-2.4 kyr BP), with denitrification dominated by changes in water column stratification inferred by high $\delta^{15} \mathrm{~N}$ and rainfall values, and low productivity values; and (2) low rainfall mode (5.8-4.4 kyr BP and 2.4 kyr BP-present), with denitrification dominated by changes in productivity, where the changes in both proxies are synchronous. Also, during the

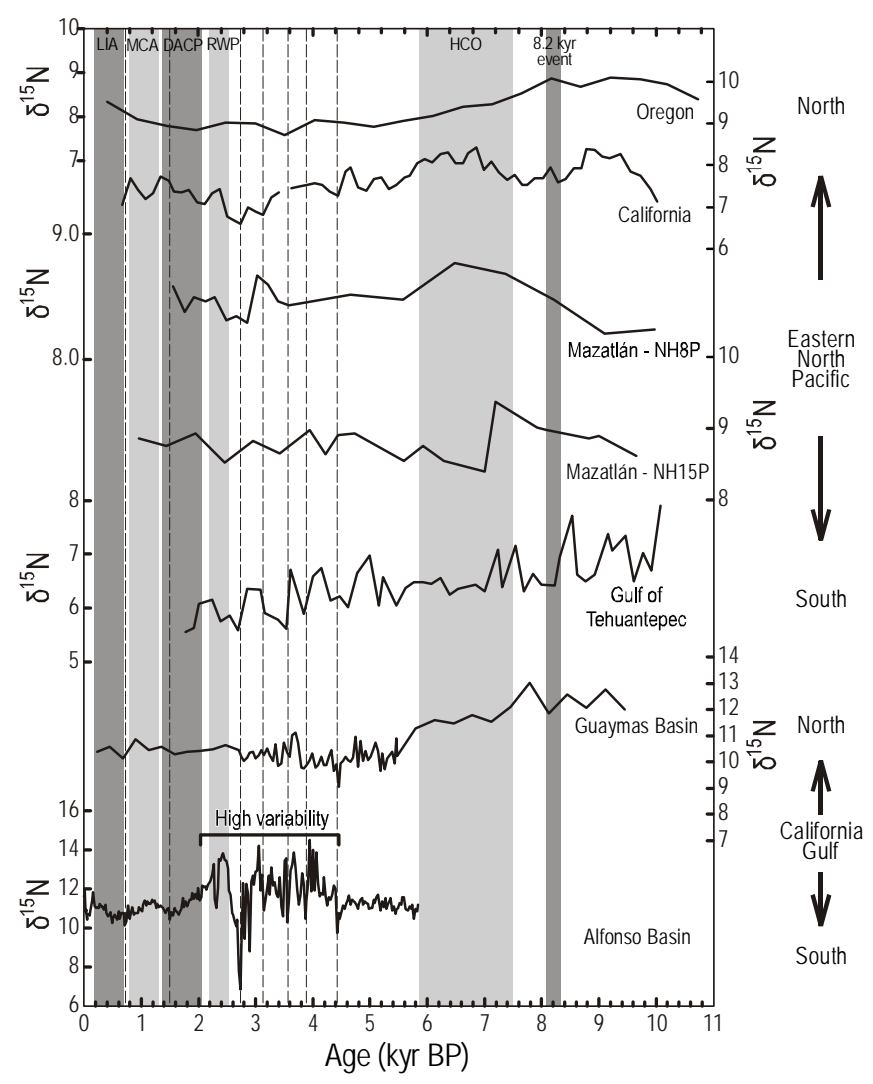

Figure 5. Bulk sedimentary $\delta^{15} \mathrm{~N}$ records during the Holocene for the eastern tropical North Pacific, California and Oregon margins (Kienast et al. 2002), Mazatlán margin (Ganeshram et al. 2000), and Gulf of Tehuantepec (Hendy and Pedersen 2006); and the Gulf of California, Guaymas Basin (Pride et al. 1999) and Alfonso Basin (this work). LIA = Little Ice Age; $\mathrm{MCA}=$ Medieval Climate Anomaly; DACP $=$ Dark Ages Cold Period; RWP = Roman Warm Period; $\mathrm{HCO}=$ Holocene Climate Optimum.

Figura 5. Registros de $\delta^{15} \mathrm{~N}$ sedimentario durante el Holoceno para el Pacífico nororiental tropical, márgenes de California y Oregon (Kienast et al. 2002), margen de Mazatlán (Ganeshram et al. 2000), y golfo de Tehuantepec (Hendy y Pedersen 2006); y el golfo de California, cuenca de Guaymas (Pride et al. 1999) y cuenca Alfonso (este trabajo). LIA= Pequeña Edad de Hielo; $\mathrm{MCA}=$ Anomalía Climática Medieval; DACP = Período Frío de la Edad Oscura; RWP = Período Cálido Romano; $\mathrm{HCO}=$ Óptimo Climático del Holoceno.

Kiel 1995), y el contenido de oxígeno del agua de fondo (Hartnett et al. 1998). Por lo tanto, la tasa de carbono orgánico enterrado en los sedimentos no puede ser extrapolada linealmente a la producción exportada (Berger et al. 1989).

En otras zonas del GC, como la cuenca de Guaymas (Sancetta 1995), se ha observado que los procesos que controlan el contenido de oxígeno del agua de fondo no se determinan por las condiciones de productividad superficial sino posiblemente por el contenido de oxígeno de las aguas 

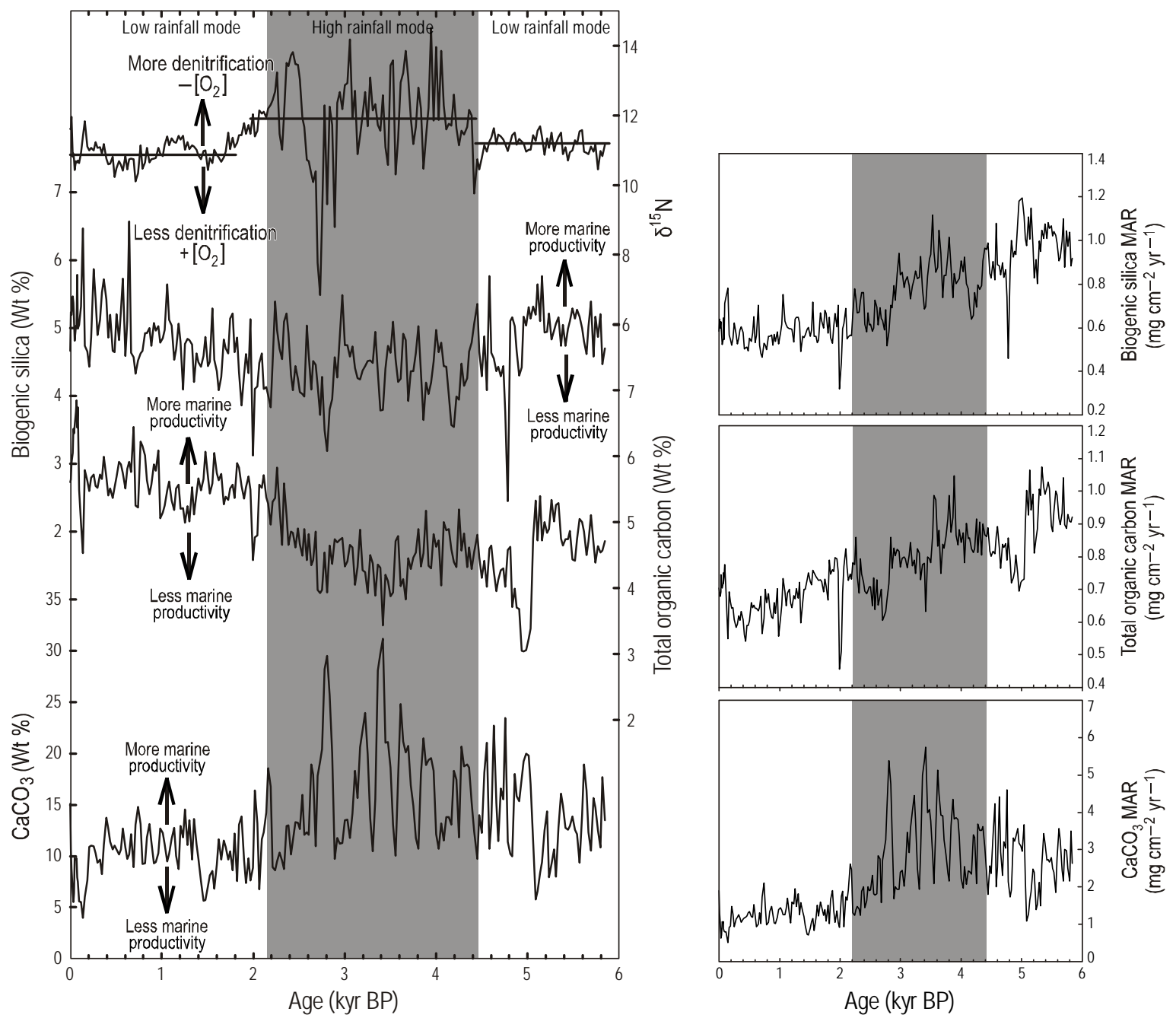

Figure 6. Bulk sedimentary $\delta^{15} \mathrm{~N}$ (denitrification indicator) and marine productivity records of Alfonso Basin: percent biogenic silica, total organic carbon, and calcium carbonate $\left(\mathrm{CaCO}_{3}\right)$. Right side: biogenic silica, total organic carbon, and $\mathrm{CaCO}_{3}$ mass accumulation rates (MAR).

Figura 6. Registros de $\delta^{15} \mathrm{~N}$ sedimentario (indicador de la desnitrificación) y de la productividad marina de la cuenca Alfonso: porcentaje de sílice biogénico, carbono orgánico total y carbonato de calcio $\left(\mathrm{CaCO}_{3}\right)$. Lado derecho: tasas de acumulación de masa (MAR) de sílice biogénico, carbono orgánico total y $\mathrm{CaCO}_{3}$.

high pluvial precipitation period, the $\delta^{15} \mathrm{~N}$ signal is decoupled of sedimentation (responding to physical mechanisms, high water-column stratification due to rainfall, generating anoxia). During the period in which productivity is coupled to denitrification (low rainfall mode), the sedimentation and local preservation of $\mathrm{BSi}$ and $\mathrm{CaCO}_{3}$ are not well coupled to the organic carbon, most likely because $\mathrm{BSi}$ and $\mathrm{CaCO}_{3}$ originate from different groups of producers that respond to different ocean-climate conditions and also because during transport and accumulation different processes act over these proxies. Furthermore, TOC has limitations as a tracer since the exported organic carbon fraction preserved in the sediments is not constant over time and space, since it depends on multiple factors such as surface productivity, seasonality intermedias que ingresan al GC, lo que sugiere que la desnitrificación es principalmente controlada por mecanismos físicos. En la cuenca Alfonso, este mecanismo parece estar relacionado con la inhibición de la mezcla vertical debido a una mayor estratificación de la columna de agua a causa de un aumento de la precipitación y aporte de agua dulce junto con una mayor advección lateral de ASS, lo cual coincide con un estudio de una trampa de sedimento recolectada en la cuenca entre 2002 y 2005 (Aguíniga et al. 2010).

El análisis de MTM de $\delta^{15} \mathrm{~N}, \%$ MOT y anomalías de dIST (fig. 7) mostró variación a la misma escala, multidecadal (50 a 85 años, frecuencia entre 0.011 y 0.02 ciclos por año), que es típica de forzamientos como la ODP (Mantua et al. 1997) y de oscilaciones climáticas identificadas previamente para 
(Berger et al. 1989), sedimentation rate (Müller and Suess 1979), sediment grain size and surface area (Hedges and Kiel 1995), and bottom-water oxygen content (Hartnett et al. 1998). Therefore, the rate of organic carbon buried in the sediments cannot be linearly extrapolated to the exported production (Berger et al. 1989).

Other areas of the GC, such as Guaymas Basin (Sancetta 1995), have shown that the processes controlling the oxygen content of bottom water are not determined by the conditions of surface productivity but possibly by the oxygen content of intermediate waters entering the GC, suggesting that physical mechanisms may be the dominant control on denitrification. In Alfonso Basin this mechanism appears to be related to inhibition of vertical mixing due to increased water column stratification caused by increased rainfall and freshwater input coupled with greater lateral advection of SSW, coincident with a study of a sediment trap collected in the basin between 2002 and 2005 (Aguíniga et al. 2010).

The MTM analysis of $\delta^{15} \mathrm{~N}, \% \mathrm{TOM}$, and dTSI anomalies (fig. 7) showed that the records shift in the same multidecadal scale ( 50 to 85 years, frequency between 0.011 and 0.02 cycles $\mathrm{yr}^{-1}$ ) as that typical of forcings such as the PDO (Mantua et al. 1997), and that of climatic oscillations identified previously for North America and the North Pacific (50 to 70 years) from instrumental data and tree-ring reconstruction of air temperatures (Minobe 1997). The occurrence of a robust decadal periodicity in the sedimentary $\delta^{15} \mathrm{~N}$ and terrestrial organic matter shows that the rainfall responds to North Pacific decadal climate variability. This is consistent with the findings of Barron and Anderson (2011) for Northeast Pacific proxy records. They propose that late Holocene climate variability in North America has been primarily driven by westto-east flow influenced by North Pacific ocean-atmosphere dynamics such as ENSO and PDO. Our record from Alfonso Basin cannot resolve ENSO-like variability, but positive PDO-like climate variability was enhanced at $4200 \mathrm{cal}$ yr BP.

\section{CONCLUSIONS}

Bulk sedimentary $\delta^{15} \mathrm{~N}$ record of Alfonso Basin showed changes of regional origin, possibly associated with changes in the isotopic signal of SSW arriving at the basin. However, $\delta^{15} \mathrm{~N}$ values higher than other records suggest that active denitrification occurred in Alfonso Basin in the past, probably from a climate source governed by solar forcing (TSI) acting over the North American monsoon strength, where increased rainfall (increase in \%TOM and $\mathrm{C}: \mathrm{N}$ ratio) leads to increased water column stratification and therefore lower $\mathrm{O}_{2}$ content; this in turn results in increased denitrification. The contribution of the isotopic signal of land-derived organic matter to the $\delta^{15} \mathrm{~N}$ values is low. The marine productivity and denitrification relationship shows two modes of basin response: a high rainfall mode (denitrification dominated by changes in stratification) and a low rainfall mode (denitrification dominated by changes in productivity). The records shift

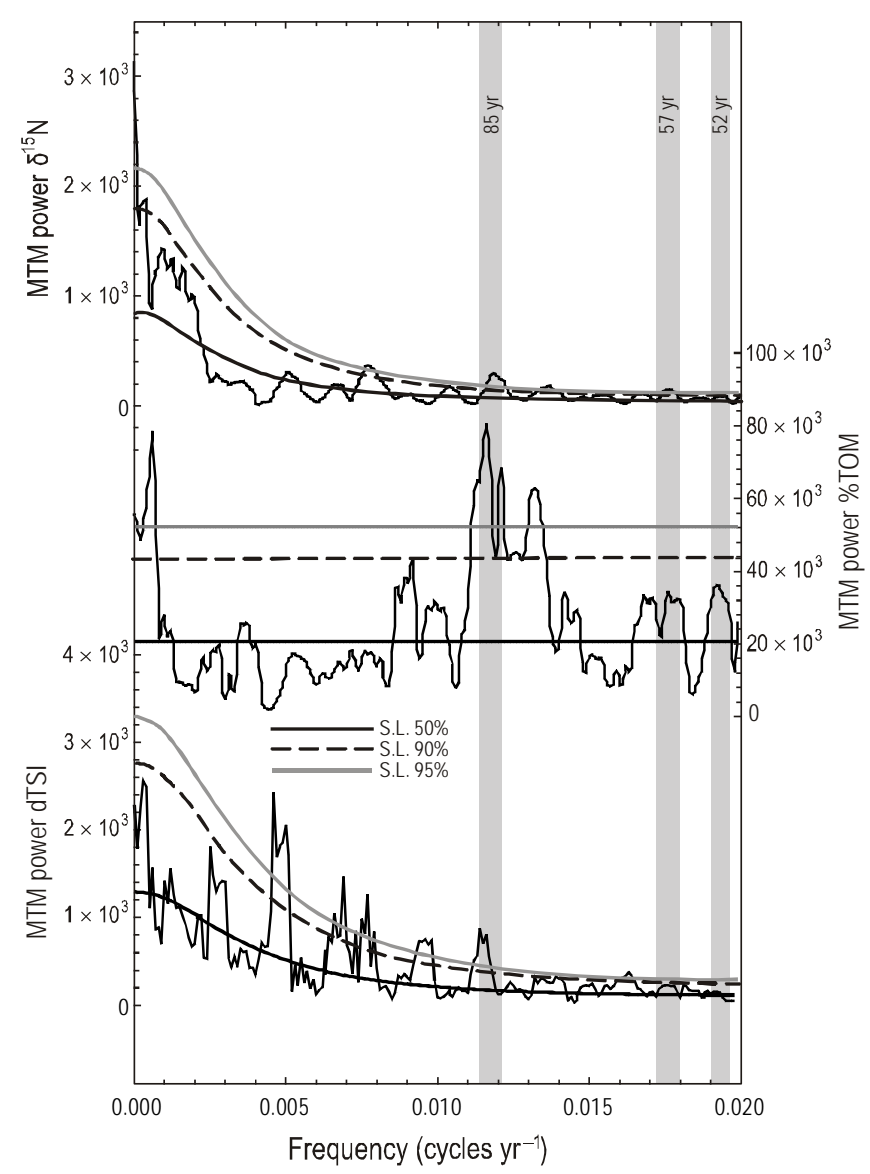

Figure 7. Multi-taper spectral analysis (MTM, Mann and Lees $1996)$ of $\delta^{15} \mathrm{~N}$, percent of land-derived organic matter (\%TOM), and anomalies of the difference of total solar irradiance (dTSI). S.L. indicates significance levels of $50 \%, 90 \%$, and $95 \%$. The gray bars show the periods in which the three series agree in frequency.

Figura 7. Análisis espectral multitaper (MTM, Mann y Lees 1996) de $\delta^{15} \mathrm{~N}$, porcentaje de materia orgánica de origen terrestre (\%TOM) y anomalías de la diferencia de irradiación solar total (dTSI). S.L. indica niveles de significación de 50\%, 90\% y 95\%. Las barras grises muestran los periodos en que las tres series concuerdan en frecuencia.

Norteamérica y el Pacífico Norte (50 a 70 años) a partir de datos instrumentales y la reconstrucción de anillos de árboles de la temperatura del aire (Minobe 1997). La robusta periodicidad decadal observada para la materia orgánica terrestre y $\delta^{15} \mathrm{~N}$ sedimentario muestra que la precipitación pluvial responde a la variabilidad climática decadal del Pacífico Norte. Esto coincide con lo documentado por Barron y Anderson (2011) para registros del Pacífico nororiental. Estos autores proponen que la variabilidad climática del Holoceno tardío en Norteamérica ha sido principalmente controlada por el flujo de oeste a este influenciado por la dinámica océanoatmósfera del Pacífico Norte (e.g., El Niño y ODP). Nuestro registro para la cuenca Alfonso no puede resolver una variabilidad de tipo El Niño, pero se observa una variabilidad climática positiva de tipo ODP a 4200 años cal AP. 
together at intervals of 50 to 85 years, a variability previously identified for North America and the North Pacific, and associated with the PDO.

\section{ACKNOWLEDGMENTS}

Funding for this work was provided by the National Council for Science and Technology (CONACYT, Mexico, grant CB-2007-01-803 to OGY). Funding for CRV was provided by a postgraduate scholarship from CONACYT. Carbon isotope analyses were made at CICIMAR-IPN through project SIP20110143 to AS. We appreciate the constructive preliminary review of this manuscript by Stephanie Kienast. The paper benefited greatly from the formal reviews and suggestions of William Berelson (USC), Caty Tems (USC), Jason A Addison (USGS), and one anonymous reviewer.

\section{REFERENCES}

Aguíñiga S, Sánchez A, Silverberg N. 2010. Temporal variations of $\mathrm{C}, \mathrm{N}, \delta^{13} \mathrm{C}$, and $\delta^{15} \mathrm{~N}$ in organic matter collected by a sediment trap at Cuenca Alfonso, Bahía de La Paz, SW Gulf of California. Cont. Shelf Res. 30: 1692-1700. http://dx.doi.org/10.1016/j.csr.2010.07.005

Altabet MA. 2006. Isotopic tracers of the marine nitrogen cycle. In: Volkman J (ed.), Marine Organic Matter: Chemical and Biological Markers. The Handbook of Environmental Chemistry. Springer-Verlag, pp. 251-293. http://dx.doi.org/10.1007/698_2_008

Altabet MA, Francois R. 1994. Sedimentary nitrogen isotopic ratio as a recorder for surface ocean nitrate utilization. Global Biogeochem. Cycles 8: 103-116. http://dx.doi.org/10.1029/93GB03396

Altabet MA, Francois R, Murray DW, Prell WL. 1995. Climaterelated variations in denitrification in the Arabian Sea from sediment ${ }^{15} \mathrm{~N} /{ }^{14} \mathrm{~N}$ ratios. Nature 373: 506-509.

http://dx.doi.org/10.1038/373506a0

Altabet MA, Pilskaln C, Thunell R, Pride C, Sigman D, Chavez F, Francois R. 1999. The nitrogen isotope biogeochemistry of sinking particles from the margin of the eastern North Pacific. Deep-Sea Res. (I) 46: 655-679. http://dx.doi.org/10.1016/S0967-0637(98)00084-3

Barron JA, Anderson L. 2011. Enhanced Late Holocene ENSO/ PDO expression along the margins of the eastern North Pacific. Quatern. Int. 235: 3-12. http://dx.doi.org/10.1016/j.quaint.2010.02.026

Berger WH, Smetacek VS, Wefer G. 1989. Ocean productivity and paleoproductivity: An overview. In: Berger WH, Smetacek VS, Wefer G (eds.), Productivity of the Oceans Present and Past: Report of the Dahlem Workshop on Productivity of the Ocean. Life Sciences Research Reports 44. Wiley, Chichester, pp. 1-34.

Calvert SE, Pedersen TF, Karlin RE. 2001. Geochemical and isotopic evidence for post-glacial palaeoceanographic changes in Saanich Inlet, British Columbia. Mar. Geol. 174: 287-305. http://dx.doi.org/10.1016/S0025-3227(00)00156-0

Cannariato KG, Kennett JP. 1999. Climatically related millennialscale fluctuations in strength of California margin oxygenminimum zone during the past $60 \mathrm{k} . \mathrm{y}$. Geology 27: 975-978. http://dx. doi.org/10.1130/0091-7613

\section{CONCLUSiOnes}

El registro de $\delta^{15} \mathrm{~N}$ sedimentario de la cuenca Alfonso mostró cambios de origen regional, posiblemente asociados con cambios en la señal isotópica del ASS que ingresa a la cuenca. No obstante, los altos valores de $\delta^{15} \mathrm{~N}$, más altos que otros registros, sugieren una desnitrificación activa en la cuenca en el pasado, probablemente de origen climático regido por el forzamiento solar (IST) que actúa sobre la intensidad del monzón de Norteamérica, donde un aumento de la precipitación pluvial (incremento del \%MOT y la razón $\mathrm{C}: \mathrm{N})$ resulta en mayor estratificación de la columna de agua $y$, por lo tanto, menor contenido de $\mathrm{O}_{2}$, que a su vez resulta en mayor desnitrificación. La contribución de la señal isotópica de la materia orgánica terrestre al valor de $\delta^{15} \mathrm{~N}$ es baja. La relación entre la productividad marina y la desnitrificación muestra dos modos de respuesta de la cuenca: un modo de alta precipitación pluvial (desnitrificación dominada por cambios en la estratificación) y un modo de baja precipitación pluvial (desnitrificación dominada por cambios en la productividad). Los registros cambian en intervalos de 50 a 85 años, una variabilidad identificada previamente para Norteamérica y el Pacífico Norte, y asociada con la ODP.

\section{Agradecimientos}

Este trabajo fue financiado por el Consejo Nacional de Ciencia y Tecnología (CONACYT, México, proyecto CB2007-01-803 a OGY). CRV fue apoyada por una beca del CONACYT. Los análisis de isótopos de carbono se realizaron en CICIMAR-IPN a través del proyecto SIP20110143 a AS. Agradecemos a Stephanie Kienast su constructiva revisión preliminar del manuscrito, así como las revisiones y sugerencias formales de William Berelson (USC), Caty Tems (USC), Jason A Addison (USGS) y un revisor anónimo que permitieron mejorar el artículo.

Traducido al español por Christine Harris.

Castro CL, McKee TB, Pielke RA. 2000. The climatology and interannual variability of the North American monsoon as revealed by the NCEP/NCAR reanalysis. Preprints. American Meteorological Society, 11th Symposium on Global Change Studies, Long Beach, CA, pp. 168-171.

Cline JD, Kaplan JR. 1975. Isotopic fractionation of dissolved nitrate during denitrication in the eastern tropical North Pacific. Mar. Chem. 3: 271-299. http://dx.doi.org/10.1016/0304-4203(75)90009-2

Codispoti LA, Christensen JP. 1985. Nitrification, denitrification and nitrous oxide cycling in the eastern tropical South Pacific Ocean. Mar. Chem. 16: 277-300. http://dx.doi.org/10.1016/0304-4203(85)90051-9

Devol A. 1978. Bacterial oxygen uptake kinetics as related to biological processes in oxygen deficient zones of the oceans. Deep-Sea Res. 25: 137-146.

http://dx.doi.org/10.1016/0146-6291(78)90001-2 
Douglas RG, Gorsline D, Grippo A, Granados I, GonzálezYajimovich O. 2001. Holocene ocean-climate variations in Alfonso Basin, Gulf of California, Mexico. In: West GJ, Buffaloe LD (eds.), Proceedings of the 18th PACLIM Workshop, Asilomar, Pacific Grove, CA, pp. 7-20

Douglas RG, González-Yajimovich O, Ledesma-Vázquez J, StainesUrias F. 2007. Climate forcing, primary production and the distribution of Holocene biogenic sediments in the Gulf of California. Quat. Sci. Rev. 26: 115-129.

http://dx.doi.org/10.1016/j.quascirev.2006.05.003

Francois R, Altabet MA, Burckle LH. 1992. Glacial to interglacial changes in surface nitrate utilization in the Indian sector of the Southern Ocean as recorded by sediment $\delta^{15} \mathrm{~N}$. Paleoceanography 7: 589-606. http://dx.doi.org/10.1029/92PA01573

Frohlich C. 2009. Evidence of a long-term trend in total solar irradiance. Astron. Astrophys. 501: 27-30. http://dx.doi.org/10.1051/0004-6361/200912318

Ganeshram RS, Pedersen TF, Calvert SE, Murray JW. 1995. Large changes in oceanic nutrient inventories from glacial to interglacial periods. Nature 376: 755-758. http://dx.doi.org/10.1038/376755a0

Ganeshram RS, Pederson TF, Calvert SE, McNeill GW, Fontugne MR. 2000. Glacial-interglacial variability in denitrification in the world's oceans: Causes and consequences. Paleoceanography 15: 361-376. http://dx.doi.org/10.1029/1999PA000422

González-Yajimovich O. 2004. Holocene sedimentation in the southern Gulf of California and its climatic implications. PhD thesis, University of Southern California, Los Angeles, 211 pp.

González-Yajimovich O, Douglas RG, Gorsline DS. 2004. Holocene record of ocean-climate variation in the Gulf of California: Rainfall and productivity. Proceedings of the 21st Annual Pacific Climate Workshop, Tech. Rep. 77, pp. 59-68.

González-Yajimovich OE, Gorsline DS, Douglas RG. 2007. Frequency and sources of basin floor turbidites in Alfonso Basin, Gulf of California, Mexico: Products of slope failures. Sediment. Geol. 199: 91-105. http://dx.doi.org/10.1016/j.sedgeo.2005.09.025

Gray ST, Betancourt JL, Fastie CL, Jackson ST. 2003. Patterns and sources of multidecadal oscillations in drought-sensitive treering records from the central and southern Rocky Mountains. Geophys. Res. Lett. 30: 1316. http://dx.doi.org/10.1029/2002GL016154

Hartnett HE, Keil RG, Hedges JI, Devol AH. 1998. Influence of oxygen exposure time on organic carbon preservation in continental margin sediments. Nature 391: 572-574. http://dx.doi.org/10.1038/35351

Hebbeln D, Marchant M, Freudenthal T, Wefer G. 2000. Surface sediment distribution along the Chilean continental slope related to upwelling and productivity. Mar. Geol. 164: 119-137. http://dx.doi.org/10.1016/S0025-3227(99)00129-2

Hedges JI, Keil RG. 1995. Sedimentary organic matter preservation: An assessment and speculative synthesis. Mar. Chem. 49: 81115 . http://dx.doi.org/10.1016/0304-4203(95)00008-F

Hedges JI, Clark WA, Quay PD, Richey JE, Devol AH, Santos UM. 1986. Compositions and fluxes of particulate organic matter in the Amazon River. Limnol. Oceanogr. 31: 717-738. http://dx.doi.org/10.4319/1o.1986.31.4.0717

Hendy IL, Kennett JP. 2003. Tropical forcing of North Pacific intermediate water distribution during Late Quaternary rapid climate change? Quat. Sci. Rev. 22: 673-689. http://dx.doi.org/10.1016/S0277-3791(02)00186-5
Hendy IL, Pedersen TF. 2006. Oxygen minimum zone expansion in the eastern tropical North Pacific during deglaciation. Geophys. Res. Lett. 33: L20602.

http://dx.doi.org/10.1029/2006GL025975

Holmes ME, Muller PJ, Schneider RR, Segl M, Patzold J, Wefer G. 1996. Stable nitrogen isotopes in Angola Basin surface sediments. Mar. Geol. 134: 1-12. http://dx.doi.org/10.1016/0025-3227(96)00031-X

Holz C, Stuut JBW, Henrich R, Meggers H. 2007. Variability in terrigenous sedimentation processes off northwest Africa and its relation to climate changes: Inferences from grain-size distributions of a Holocene marine sediment record. Sediment. Geol. 202: 499-508.

http://dx.doi.org/10.1016/j.sedgeo.2007.03.015

$\mathrm{Hu} \mathrm{Q}$, Feng S. 2002. Interannual rainfall variations in the North American summer monsoon region: 1900-98. J. Climate 15: 1189-1202.

http://dx.doi.org/ 10.1175/1520-0442(2002)015<1189:IRVITN> 2.0.CO;2

Keigwin LD, Jones GA. 1990. Deglacial climatic oscillations in the Gulf of California. Paleoceanography 5: 1009-1023. http://dx.doi.org/10.1029/PA005i006p01009

Kennett JP, Ingram BL. 1995. A 20,000-year record of ocean circulation and climate change from the Santa Barbara Basin. Nature 377: 510-514. http://dx.doi.org/10.1038/377510a0

Kienast SS, Calvert SE, Pedersen TF. 2002. Nitrogen isotope and productivity variations along the northeast Pacific margin over the last 120 kyr: Surface and subsurface paleoceanography. Paleoceanography 17: 1055. http://dx.doi.org/10.1029/2001pa000650

Lavín MF, Niiler P, Amador A, Castro R, Beier E. 2007. Surface velocity patterns in the Gulf of California from satellite-tracked drifters. American Geophysical Union 2007 Joint Assembly, Acapulco, 22-25 May, Abstract on CD, OS51D-02.

Liu KK, Kaplan IR. 1989. The eastern tropical Pacific as a source of ${ }^{15} \mathrm{~N}$-enriched nitrate in seawater off southern California. Limnol. Oceanogr. 34: 820-830.

Magaña V. 1999. Los Impactos de El Niño en México. Dirección General de Protección Civil, Secretaría de Gobernación, México. 229 pp.

Mann ME, Lees JM. 1996. Robust estimation of background noise and signal detection in climatic time series. Clim. Change 33: 409-445. http://dx.doi.org/10.1007/BF00142586

Mantua NJ, Hare SR, Zhang Y, Wallace JM, Francis RC. 1997. A Pacific interdecadal climate oscillation with impacts on salmon production. Bull. Am. Meteor. Soc. 78: 1069-1079.

http://dx.doi.org/10.1175/15200477(1997)078<1069:APICOW >2.0.CO;2

Meckler AN, Haug GH, Sigman DM, Plessen B, Peterson LC, Thierstein HR. 2007. Detailed sedimentary N isotope records from Cariaco Basin for Terminations I and V: Local and global implications. Global Biogeochem. Cycles 21, GB4019 http://dx.doi.org/10.1029/2006GB002893.

Meyers PA. 1994. Preservation of elemental and isotopic source identification of sedimentary organic matter. Chem. Geol. 114: 289-302. http://dx.doi.org/10.1016/0009-2541(94)90059-0

Minobe S. 1997. A 50-70 year climatic oscillation over the North Pacific and North America. Geophys. Res. Lett. 24: 683-686. http://dx.doi.org/10.1029/97GL00504

Monreal-Gómez MA, Molina-Cruz A, Salas-de León DA. 2001. Water masses and cyclonic circulation in La Paz Bay, Gulf of California, during June 1998. J. Mar. Syst. 30: 305-315. http://dx.doi.org/10.1016/S0924-7963(01)00064-1 
Mortlock RA, Froelich PN. 1989. A simple method for the rapid determination of biogenic opal in pelagic marine sediments. Deep-Sea Res. (A) 36: 1415-1426.

http://dx.doi.org/10.1016/0198-0149(89)90092-7

Müller PJ, Suess E. 1979. Productivity, sedimentation rate and sedimentary organic matter in the oceans. I. Organic carbon preservation. Deep-Sea Res. 26: $1347-1362$. http://dx.doi.org/10.1016/0198-0149(79)90003-7

Nava-Sánchez EH, Gorsline DS, Molina-Cruz A. 2001. The Baja California peninsula borderland: Structural and sedimentological characteristics. Sediment. Geol. 144: 63-82. http://dx.doi.org/10.1016/S0037-0738(01)00135-X

Obeso-Nieblas M. 2003. Variabilidad espaciotemporal de las condiciones oceanográficas de la Bahía de La Paz. PhD thesis, CICIMAR, Instituto Politecnico Nacional, 337 pp.

Obeso-Nieblas M, Shirasago-Germán B, Gaviño-Rodríguez JH, Obeso-Huerta H, Pérez-Lezama EL, Jiménez-Illescas AR. 2007. Hydrography at the North Mouth of La Paz Bay, Baja California Sur, Mexico. Cienc. Mar. 33: 281-291.

Owens NJP, Law CS. 1989. Natural variations in ${ }^{15} \mathrm{~N}$ content of riverine and estuarine sediments. Estuar. Coast. Shelf Sci. 28: 407-416. http://dx.doi.org/10.1016/0272-7714(89)90088-7

Pérez-Cruz L. 2013. Hydrological changes and paleoproductivity in the Gulf of California during middle and late Holocene and their relationship with ITCZ and North American Monsoon variability. Quat. Res. 79: 138-151. http://dx.doi.org/10.1016/j.yqres.2012.11.007

Peters KE, Sweeney RE, Kaplan IR. 1978. Correlation of carbon and nitrogen stable isotope ratios in sedimentary organic matter. Limnol. Oceanogr. 23: 598-604.

Poore RZ, Pavich MJ, Grissino-Mayer HD. 2005. Record of the North American southwest monsoon from Gulf of Mexico sediment cores. Geology 33: 209-212. http://dx.doi.org/10.1130/G21040.1

Pride C, Thunell R, Sigman D, Keigwin L, Altabet M, Tappa E. 1999. Nitrogen isotopic variations in the Gulf of California since de last deglatiation: Response to global climate change. Paleoceanography 14: 397-409. http://dx.doi.org/10.1029/1999PA900004

Sancetta C. 1995. Diatoms in the Gulf of California: Seasonal flux patterns and the sediment record for the last 15,000 years. Paleoceanography 10: 67-84. http://dx.doi.org/10.1029/94PA02796

Schultz D, Calder JA. 1976. Organic carbon $13 \mathrm{C} / 12 \mathrm{C}$ variations in estuarine sediments. Geochim. Cosmochim. Acta 40: 381-385. http://dx.doi.org/10.1016/0016-7037(76)90002-8
Sánchez A, López-Ortiz BE, Aguíñiga S, Balart E. 2013. Distribution and composition of organic matter in sediments of the oxygen minimum zone of the northeastern Mexican Pacific. J. Iber. Geol. 39:111-120.

Sigman D. 2001. Ocean nutrient cycling: Today and in the past. The Smilodon. Princeton Geosciences Newsletter 42: 1-5.

Silverberg N, Martínez A, Aguíñiga S, Carriquiry JD, Romero N, Shumilin E, Cota S. 2004. Contrasts in sedimentation flux below the southern California Current in late 1996 and during the El Niño event of 1997-1998. Estuar. Coast. Shelf Sci. 59: 575-587. http://dx.doi.org/10.1016/j.ecss.2003.11.003

Steinhilber F, Beer J, Frohlich C. 2009. Total solar irradiance during the Holocene. Geophys. Res. Lett. 36, L19704. http://dx.doi.org/10.1029/2009GL040142

Stuiver M, Reimer P. 1993. Extended ${ }^{14} \mathrm{C}$ database and revised CALIB radiocarbon calibration program. Radiocarbon 35: 215-230.

Sweeney RE, Liu KK, Kaplan IR. 1978. Oceanic nitrogen isotopes and their uses in determining the source of sedimentary nitrogen. In: Robinson BW (ed.), Stable Isotope in the Earth Science. New Zealand Department of Scientific and Industrial Research, Wellington, pp. 9-26.

Thunell RC. 1998. Seasonal and annual variability in particle fluxes in the Gulf of California: A response to climate forcing. DeepSea Res. (I) 45: 2059-2083. http://dx.doi.org/10.1016/S0967-0637(98)00053-3

Van Geen A, Fairbanks RG, Dartnell P, McGann M, Gardner JV, Kashgarian M. 1996. Ventilation changes in the northeast Pacific during the last deglaciation. Paleoceanography 11: 519-528. http://dx.doi.org/10.1029/96PA01860

Van Geen A, Zheng Y, Bernhard JM, Cannariato KG, Carriquiry J, Dean WE, Eakins BW, Ortiz JD, Pike J. 2003. On the preservation of laminated sediments along the western margin of North America. Paleoceanography 18: 1098. http://dx.doi.org/10.1029/2003PA000911

Versteegh GJM, Zonneveld KAF. 2002. Use of selective degradation to separate preservation from productivity. Geology 30: 615-618. http://dx.doi.org/10.1130/0091-7613

Zhao M, Mercer JL, Eglinton G, Higginson MJ, Huang C-Y. 2006. Comparative molecular biomarker assessment of phytoplankton paleoproductivity for the last $160 \mathrm{kyr}$ off Cap Blanc, NW Africa. Org. Geochem. 37: 72-97. http://dx.doi.org/10.1016/j.orggeochem.2005.08.022

Received September 2012, received in revised form February 2013, accepted March 2013. 